much less temperate one than $I$ hope and expect you will consider it to be.

If a new operation be started, or a new system of treatment introduced, no matter how wrong and absurd they may be, the way to ensure success to either one or the other is to run it down and express strong opinions against it. But as I am anxious that the very questionable operation performed by $\mathrm{Mr}$. Baker Brown for the cure of epilepsy should not gain ground, I would ask my professional brethren not to persecute $\mathrm{Mr}$. Brown and his followers or to speak too disparagingly of their treatment, but to publish whatever facts may come to their knowledge, either for or against; for I think such a course would lead to its discontinuance, simply because (as is my firm belief) we should find the number of cases permanently cured to be very few and far between.

I have at the present time under my care a lady, aged twenty-six, who has been epileptic ever since she was four years old. She was admitted into the Surgical Home a short time ago, underwent the "operation as before," suffered intense pain afterwards, and thirteen weeks after admission was discharged, if not cured, greatly benefited. But a month had not passed before her fits returned with a severity never before equalled, and she is now as bad as ever.

This is my mite; let other members of the profession contribute theirs, and I think in a short time the "operation as before" will either be forgotten, or thought of by those who do remember it with horror and indignation.

I am, Sir, your obedient servant,

Harry Gage Moore, L.R.C.P. Lond.

Northgaterstreet, Ipswich, June 2, 1866 .

\section{THE INTRA-UI'ERINE SPRING PESSARY.} To the Editor of THE LANCET.

SIR,-The questions which Dr. Greenhalgh reiterates with such pertinacity have been already fully answered, as your readers will find on referring to my letter of May 5th, and to the communications from Dr. Aveling and Sir J. Y. Simpson (May 12). The use of the intra-uterine spring, claimed as his invention by Dr. Greenhalgh, was adopted in 1855 by Dr. Martin Weir. This was long antecedent to any mention of the use of a spring which I had elsewhere met with. I never claimed as my own the first application of a spring; it merely formed an auxiliary part of the little device described in my original paper (THE LANCET, February 4th), where I emphatically pointed out that intra-uterine appliances were only justifiable in extreme cases. In his letter of April 28th, Dr. Greenhalgh confessed his instrument to be altogether unsuitable for use in cases of uterine flexion, and very emphatically warned your readers as to the risk attending its use. It is not very clear why there was no mention made of this failure and of the danger of the instrument in his previous communication, or why the "numerous medical men in private practice in this country and on the continent" to whom Dr. Greenhalgh referred as using his instrument were still allowed to believe they possessed an instrument suitable for redressing flexions of the uterus. I am really sorry to occupy your valuable space about such an utterly trivial matter, but the note of Dr. Greenhalgh conveyed an imputation of which your readers will estimate the propriety by reference to my previous letter, in p. 487 of THE LANCET. It is very clear that his instrument has nothing whatever to do with the subject of flexions of the uterus, and should never have been employed in such cases. I am, Sir, your obedient servant,

Somerset-street, Portman-square.

H. G. WRIGHT.

\section{BRAN BISCUITS IN DIABETES.}

\section{To the Editor of THE LANCET.}

SIR, - During the past year or two I have been engaged, as opportunity allowed, in making an extensive series of analyses of various articles of food, with a view to determine their fitness or otherwise for the use of the diabetic. I had hoped ere this to have been able to put the results so obtained in a form for publication; but other engagements having intervened, I have been compelled to postpone the execution of this design.

One result obtained is, however, so important that I should scarcely be justified in refraining any longer from making it known-viz., the unfitness of the prepared bran and biscuits now sold for diabetic cases, notwithstanding the statements advanced as to the purity of the bran and its freedom from starch.

The method of purification now in use consists simply in washing and pressing the bran, whereby, doubtless, a small quantity of starch is removed; but since the starch-granules are chiefly enclosed in the cellular tissue of the bran, it is obvious that this process must be insufficient for the removal of the greater part of the starch. That it really is so may be proved in a moment by the simple application of a drop of tincture of iodine either to a small portion of the prepared bran or of one of the biscuits made therewith, when they will instantly become of a deep bluish-black colour. But the quantity actually present may be readily estimated by converting it, through the action of a little dilute sulphuric acid, into glucose or grape-sugar, which may be easily washed away, the sugar estimated, and the quantity of starch present ascertained therefrom. Some analyses made in this manner furnished the following results :-

\section{Unprepared Bran.}

Per cent.

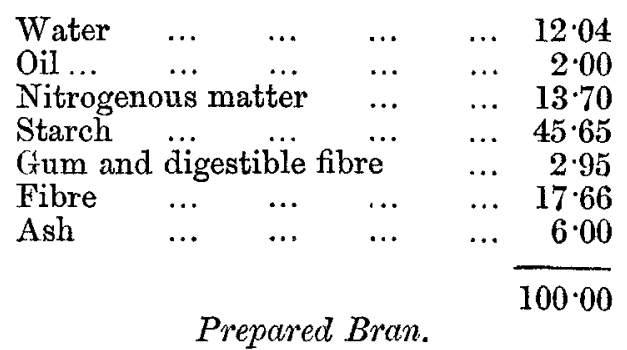

\begin{tabular}{|c|c|c|c|c|c|}
\hline \multirow{3}{*}{ Water } & & \multirow{2}{*}{\multicolumn{2}{|c|}{ Per cent. }} \\
\hline & & & & & \\
\hline & $\cdots$ & $\cdots$ & $\ldots$ & $\cdots$ & \\
\hline Oil ... & $\ldots$ & $\ldots$ & $\ldots$ & $\ldots$ & $4 \cdot 65$ \\
\hline Albumen & $\ldots$ & $\ldots$ & $\ldots$ & $\ldots$ & $15 \cdot 20$ \\
\hline Starch & & $\ldots$ & $\ldots$ & $\ldots$ & $44 \cdot 50$ \\
\hline Digestible & fibre & $\ldots$ & $\ldots$ & $\ldots$ & 77 \\
\hline Fibre & $\ldots$ & $\ldots$ & $\ldots$ & $\ldots$ & $19 \cdot 00$ \\
\hline \multirow{3}{*}{ Ash } & $\ldots$ & $\ldots$ & $\ldots$ & $\ldots$ & $5 \cdot 70$ \\
\hline & \multirow{2}{*}{\multicolumn{3}{|c|}{ Bran Biscuits. }} & & $100 \cdot 00$ \\
\hline & & & & & Per cent. \\
\hline Water & & $\ldots$ & $\ldots$ & $\ldots$ & $9 \cdot 80$ \\
\hline Oil and $b$ & utter & $\ldots$ & $\ldots$ & $\ldots$ & $28 \cdot 30$ \\
\hline Albumen & $\ldots$ & $\ldots$ & $\ldots$ & $\ldots$ & $13 \cdot 96$ \\
\hline Starch & & & $\ldots$ & $\ldots$ & $28 \cdot 20$ \\
\hline \multirow{4}{*}{$\begin{array}{l}\text { Gum and } \\
\text { Fibre } \\
\text { Ash }\end{array}$} & digest & ble & & & $5 \cdot 02$ \\
\hline & $\ldots$ & $\ldots$ & $\ldots$ & $\ldots$ & $9 \cdot 60$ \\
\hline & $\ldots$ & $\ldots$ & $\ldots$ & $\ldots$ & $5 \cdot 12$ \\
\hline & & & & & \\
\hline
\end{tabular}

The above figures demonstrate the accuracy of the statement already made, to the effect that the prepared bran and biscuits now sold are totally unfit for the use of patients labouring under diabetes. They serve also to explain the disappointment which is so generally experienced in the use of these biscuits, the urine still continuing to retain a high specific gravity and to abound in sugar. So general has the use of bran biscuits become, that the fact cannot be too generally known that they contain a very large proportion of starch and of matter con. vertible into sugar.

Now the method employed in the analysis of the samples of prepared bran and biscuits tested, with certain modifications, furnishes us with a means of freeing the bran absolutely from all starch, and of rendering it an admirable material for the preparation of really pure bran biscuits. I have had the process repeatedly carried out on a large scale, and I find that it answers completely. I further find that there is no difficulty in making from the purified bran a "flour of bran" equal in fineness to wheat flour or my "flour of meat," and thus overcoming another objection to the use of the brannamely, its coarseness.

Lastly, I would observe that the value of this "flour of bran" is greatly increased by its admixture with a portion of my "flour of beef;" and that thus a mixture is obtained more nutritive, and certainly better fitted in every respect for the treatment of diabetes, than anything hitherto devised.

I remain, Sir, your obedient servant,

Arthur Hill Hassall, M.D. Lond., Senior Physician to the Royal Free Hospital.

Wimpole-street, June 4th, 1866 . 